\title{
Svevo and the Ironic Conscience of the Novel
}

"si vedono meno bene le cose quando si spalancano troppo gli occhi""1

Beryl De Zoete's English translation of Svevo's third novel La Coscienza di Zeno as The Confessions of Zeno, is symptomatic of a major misunderstanding in what this novel is supposedly about. Whereas the original title places the stress of "coscienza" (conscience, awareness) the English translation privileges the confessional and diary-like form of the novel. In one sense De Zoete is correct because the two meanings can be said to converge in that Zeno's "coscienza" is confessed in the diary which is the novel. This convergence, however, is only apparent because the privileging of the confessional aspect of the novel not only underplays the awareness but also displaces it. "Confession" can also denote lack of awareness because in a confession the appeal is to someone else's "coscienza." To someone like an analyst, for example, capable of understanding what one cannot himself understand. De Zoete' emphasis on confession presupposes already a psychoanalytical reading of the novel or, simply, that the psychoanalytical is the dominant theme of the novel. Zeno's remark, "Ricordo tutto, ma non intendo niente" ("I remember everything, but I don't understand anything," 623), is apropos. It can easily be read as a statement that cries out for an analyst to interpret and understand. ${ }^{2}$ The reader-critic has no choice but to take the place of Zeno's analyst, Doctor S., and subject the novel to psycho-analysis. ${ }^{3}$

"Coscienza," however, can also allude to a type of awareness that need not necessarily be identified with Zeno, the blundering, inept protagonist of the novel. As every reader of the novel knows, the text often functions independently and despite Zeno Cosini's received ideas of the world around him. When Zeno's actions are prompted by his desire to be and do what is naturally beyond the range of his possibilities, things always turn out to be the opposite of what he thinks to be the case. In this ironic framework, Zeno is always the first victim of his pronouncements. His "coscienza" is always the result of an ironic predicament. The knowledge, in other words, that what we call "reality" is always different from what it initially appeared us to be. Within this context, the statement "Ricordo tutto, ma non intendo niente" instead of signifying the condition of a divided self, could be taken as a statement on the precariousness of self-understanding that puts even psychoanalytical understanding into question.

One way to get to the heart of the problem is to inquire why the protagonist of the novel is called "Zeno" or, which is the same, which philosopher is Zeno 
said to resemble. "Alberta citò un filosofo antico che doveva somigliarmi nell'interpretazione della vital ..." ("Alberta quoted an ancient philosopher whose view of life was rather like mine. . ." 662). The philosopher, as some critics have suggested, is Zeno of Elea who set out, paradoxically, to demonstrate the impossibility of motion. In one of his most famous proofs, he claimed that Achilles, the fastest runner of the Greek world, could not win a race against a tortoise. He argued that by the time Achilles caught up with the tortoise at a point $A$, the tortoise will have reached a point $B$. When Achilles covers the distance $\mathrm{AB}$, the tortoise will have reached a point $\mathrm{C}$, and so on to infinity. If we put aside for a moment the philosophical reasons behind Zeno of Elea's example, namely that it was meant to prove Parmenides' concept of plurality, the importance of the paradox for us is in the way it undermines our common expectations which dictate that anyone, and not just Achilles, is faster than a tortoise. Zeno of Elea chooses on purpose the fastest man and the slowest animal to demonstrate, instead, that our sense of perception is not to be trusted. Svevo, I would like to suggest, names his protagonist "Zeno" for similar reasons and in order to draw the reader's attention to a mode of representation which is patterned on the philosopher's method of proof. An indirect allusion to this method is made in an episode which explicitly parodies the Eleatic paradox.

Tullio s'era rimesso a parlare della sua malattia ch'era anche la sua principale distrazione. Aveva studiato l'anatomia della gamba $\mathrm{c}$ del piede. Mi raccontò ridendo che quando si cammina con passo rapido, il tempo in cui si svolge un passo non supera il mezzo secondo e che in quel mezzo sccondo si muovevano nientemeno che cinquantaquattro muscoli. Trasecolai c subito corsi col pensicro alle mie gambe a cercarvi la macchina mostruosa. Io credo di averla trovata. Naturalmente non riscontrai cinquantaquattro ordigni, ma una complicazione enorme che perdette il suo ordine dacché io ri ficcai la mia attenzione. Uscii da quel caffè zoppicando c per alcuni giorni zoppicai sempre. Il camminare era per me divenuto un lavoro pesante, e anche lievemente doloroso. A quel groviglio di congegni parcva mancasse ormai l'olio e che, muovendosi, si ledessero a vicenda. Pochi giorni appresso, fui colto da un male più grave di cui dirò $\mathrm{c}$ che diminuì il primo. Ma ancora oggidì, chc ne scrivo, se qualcuno mi guarda quando mi muovo, i cinquantaquattro movimenti s'imbarazzano ed io sono in procinto di cadere.

[Tullio and I began talking about his illness, which was his principal distraction. He had studied the anatomy of the leg and foot. He told me with amusement that when one is walking rapidly each step takes no more than half a second, and in that half second no fewer than fifty-four muscles are set in motion. I listened in bewilderment. I at once directed my attention to my legs and tried to discover the infernal machine. I thought $I$ had succecded in finding it. I could not of course distinguish all its fifty-four parts, but I discovered something terribly complicated which seemed to lose its order as soon as I began paying attention to it. I limped as I left the café and for several days afterwards. Walking had become a burden to me and even caused me a certain amount of pain. I felt as if that mass of muscles needed oiling and that in moving 
they would get damaged. A few days later I was struck by a greater calamity, which I will relate later, and which diminished the first one. But even today, if anyone watches me walking, the fifty-four movements get ticd up in a knot, and I feel like falling. (682-83, italics mine)]

The key word of the passage is "attention," which is another way of saying "coscienza" ("awareness"). Zeno in becoming aware of what lies behind the appearances of things disrupts their apparent order and reveals the hidden "macchina mostruosa," namely a knowledge, that differs from our common, complacent way of looking at the world and that is no longer reassuring. Just as Zeno limps, or is about to fall, as the result of his "attenzione," this knowledge of what actually lies behind the apparent order and logic of things makes it increasingly difficult forever after to live comfortably in the world. We shall return to the more pessimistic implications of Svevo's "coscienza" that shape the ending of the novel, for the moment we would like to identify this paradoxical approach with the ironic conscience of the novel which subverts in its wake man's mystified relation to the world. ${ }^{5}$ In the novel the "attention" is focussed on man's delusions of self-importance (Zeno's last cigarette), on the institutions of family, marriage and business and most of all, on the pretense of psychoanalysis, a science that was gaining popularity at the time Svevo was writing, to solve the problem of man. ${ }^{6}$ This preoccupation reflects the novel's structure which is not that of a traditional novel, as Svevo's earlier novels may be said to be, but consists of a series of paradoxes or ironic demystifications of order held together by the single ironic perspective of the author.

In the chapter "Il Fumo" ("Smoking"), Zeno's futile efforts to quit smoking are a parody of man's desire for change and self-improvement that are destined to come to nought. With his resolve to stop smoking, Zeno hopes to become the strong and ideal man he has always wanted to be. "Chissà se cessando di fumare io sarei divenuto l'uomo ideale e forte che m'aspettavo?" ("Who knows if by not smoking I would have become the strong and ideal man I wanted to be?" 606). Of course, the point of the chapter is to expose the deluded notion that such a change can occur and that the weak-willed Zeno can emerge a new man. Svevo parodies the traditional autobiographical novel, whose central theme is the self and its transformations, by reversing the relationship between the unique, meaningful event in the life of the self and the date that records it. In the novel it is the date that suggest the possibility of change.

Del secolo passato rice* ^ una data che mi parve dovesse sigillare per sempre la bara in cui volevo mettere il mio vizio: "Nono giorno del nono mese del 1899." Significativa neviero? II secolo nuovo $\mathrm{m}$ 'apportò delle date ben altrimenti musicali: "Primo giorno del primo mese del 1901." Ancora mi pare che se quella data potesse ripetersi, io saprei iniziare una nuova vita. 
I 1 remember a date from the last century which seemed to mark forever the end of my vice: "Ninth day of the ninth month of 1899." .Meaningful, wouldn't you say! The new century provided me with other dates equally musical. "First day of the first month of 1901." If that date could repeat itself I could begin a new life. (607, italics $\operatorname{minc})$ ]

The date acquires meaning not through the act willed but by the inner coherence and musicality of the numbers that go to make up the date. In so doing Svevo draws attention to the date as a literary device as well as to the fiction of "una nuova vita" ("a new life"), an indirect allusion to that model of all fictional autobiographies, Dante's Vita Nuora. La coscienza di Zeno, however, is a parody of the genre, an anti-autobiographical novel, not because the others are fictional and Svevo's novel is not. What is put into question by the parody is the fiction of a self caught in the illusion of temporality that makes the self believe in the possibility of change, that it can be other than it is. When this deluded view is overcome in the old Zeno who writes the diary for the confessions, the acceptance of his smoking habit corresponds to the acceptance that time does not change but always repeats itself. "Eppoi il Tempo, per me, non è quella cosa impensabile che non s'arresta mai. Da me, solo da me, ritorna" ("And anyway time for me is not that unimaginable thing that never stops. It always comes back to me, only to me," 607). In Eleatic fashion, for the "cured" Zeno time is motionless. Just as Achilles will never triumph over the tortoise, Zeno will never be the man he aspires to be. He is condemned to always be the weakling he knows himself to be. Ironically, however, it is this knowledge that for Svevo defines true health which he understands, paradoxically, as the awareness of being sick. "La miglior prova ch'io non ho avuta quella malattia risulta dal fatto che non ne sono guarito" ("The best proof that I have never had that illness is clear from the fact that I am not cured," 928). Health, in other words, is achieved through an awareness of the mystifications to which the self is subject in time. Health is the result of an attention, an ironic conscience, that undermines the self's mystifications by arresting once and for all, in eleatic fashion, the temporality that made it possible. Yet this ironic demystification is for Svevo only a temporary remedy. We shall return later to what he believes to be the remedy for man for all time.

In the chapters that follow, "La storia del mio matrimonio" ("The story of my marriage"), "La Moglie e l'Amante" ("Wife and Mistress") and "Storia di un'associazione commerciale" ("A Business Partnership"), Zeno's "attention" is directed at subverting examples of "health" and "strength" that he identifies with those around him: his own father, the father-in-law Malfenti, Ada and Guido. In typical ironic fashion Zeno's first impression of these characters couldn't be further from the truth. The old Malfenti, whom Zeno believes to be a paragon of health, dies soon after. Augusta, the ugly sister that Zeno discards as a possible mate, turns out to be the one he marries and the best catch. The beautiful Ada that Zeno pursues hopelessly later becomes sickly 
and ugly when she contracts the "morbo di Basedow" ("Basedow's disease"). Guido, the paragon of strength and health in the novel, the strong and ideal man that Ada prefers to Zeno, turns out to be an unfaithful husband, inept in business and a despicable weakling who has to resort to feigning suicide to force his wife to help him financially. He dies foolishly when his pretended suicide is not discovered in time.

Zeno's "fortune" undergoes similar changes. From being thought crazy and irresponsible he becomes respected and appreciated. From being completely inept at conducting business affairs he pulls off a crucial business deal on the stock market making a large profit. Ada who at first dislikes him and rejects him later loves him. Appearances, in other words, always prove to be deceptive and the fortune of the characters change radically to disprove Zeno's first impressions. As Zeno says of himself, he is "un buon osservatore ma un buon osservatore alquanto cieco" ("a good observer but somewhat blind," 657). The wheel of fortune, however, is never stable and if Zeno is now appreciated by his family for reasons not his own he is just as quickly put down for no reason. Ada eventually rejects Zeno accusing him unjustly of having hated Guido and of having made his death seem futile with his winnings on the stock market. Ada's false accusations have also a deeper meaning. They represent a moment in the novel which is irreversible and fixed. Soon after Ada leaves to join Guido's family in Buenos Aires never to return again, her departure from the novel deprives Zeno of the opportunity to justify his conduct and to prove her his innocence. "Ecco ch'essa ci abbandonava e che mai più avrei potuto provarle la mia innocenza" ("Now that she was leaving us I could no longer prove her my innocence," 926, italics mine). As far as the relationship with Ada is concerned, time has once again stopped, freezing in time a false image of Zeno that he will never be able to erase. In Ada's eyes Zeno has lost his innocence forever.

The episode reiterates another, the death of Zeno's father, when Zeno is faced with a similar, irreversible experience. Zeno, following the doctor's advice makes sure that his sick, but restless father remains in bed but the father dies believing (or so Zeno thinks) that the son wants to keep him prisoner in bed. "Egli era morto ed io non potevo provargli la mia innocenza!" ("He was dead and I could not prove my innocence," 645, italics mine). As in Ada's case (similar examples are Ada's father's death and Guido's death), Zeno's father's death marks a fixed moment in time when change comes to a halt and Zeno is left in a predicament that he can no longer alter. The death or departure of these characters prevent Zeno from proving to them that he is not what they think he is thus making it impossible for him to prove his innocence. Their "disappearance" condemns Zeno to "illness," that is, to endure a false image of himself forever. This situation provides us with another version of the Eleatic paradox which, if it may seem absurd in the case of Achilles and the tortoise, in the case of Zeno Cosini, or of any man for that matter, is a simple fact of life. Characters and events are 
implicated in a process where things are always the opposite of what they seem maintaining an illusion of health and change until the moment when death puts an end to both and freezes the tableau on a situation that never is what it says it is. ${ }^{7}$

The brunt of Svevo's critique, and of Zeno's irony, however, is directed at psychoanalysis and at the promise of health that Freud's theories seem to guarantee. ${ }^{8}$ The insistence of some critics to read the novel from the point of view of psychoanalysis and to ignore the critique that Svevo gives of this discipline as only the quirk of a deluded neurotic goes only to emphasize how strong the desire of health is in everyone of us. Nor can the apparent critique of psychoanalysis be attributed to Zeno's "antipatia" ("dislike") for his analyst, Dr. S. as the latter would like us to believe. "Chi di psicoanalisi s'intende sa dove piazzare l'antipatia che il paziente mi dedica" ("Anyone familiar with psychoanalysis will know to what to attribute my patient's hostility," 599). In Svevo's critique it is psychoanalysis's inability to discriminate between truth and lie which is in question. Svevo characterizes Doctor S. as a man who believes everything he reads forgetting that man lies easily. This is not to say that for Svevo man is a liar, but that very often, when words fail him, he says the first thing that comes to mind. Man speaks of one thing rather than another not because it may be important but because he easily forgets and says only the things for which he can find the words.

Il dottore presta una fede troppo grande anche a quelle mie benedette confessioni che non vuole restituirmi perché le riveda. Dio mio! Egli non studiò che la medicina e perciò ignora che cosa significhi scrivere in italiano per noi che parliamo e non sappiamo scrivere il dialetto. Con ogni nostra parola toscana noi mentiamo! Se egli sapesse come raccontiamo con predilezione tutle le cose per le quali abbiamo pronta la frase e come evitiamo quelle che ci obbligherebbero di ricorrere al vocabolario! E' proprio cosi che scegliamo dalla nostra vita gli episodi da notarsi. Si capisce come la nostra vita avrebbe tutt'altro aspetto se fosse detta nel nostro dialetto.

[The doctor attaches too much importance to those confessions of minc, which he refused to give back so that I may look at them again. My God! He has only studicd medicine, and so he has no idea what it means for us who talk and write in dialect to write in Italian. We lie with every word we speak in the Tuscan tongue! If he only knew how we like to talk about things for which we have ready the words, and how we avoid subjects which would oblige us to look up words in the dictionary! That is how we choose from our lives episodes of note. Naturally our life would take on quite a different aspect if it were told in our dialect. (928, italics mine)]

The opposition "toscano"/"dialetto," very much apropos in the case of the Trieste born, german-speaking Italo Svevo/Ettore Schmitt, does not imply that if Zeno were to spcak in his dialect he could tell the truth. The opposition emphasizes a difference between a universal language of communication common to everyone and a personal, original language, that alone is capable of expressing clearly and distinctly all of one's thoughts and feelings. The 
latter, however, is a language not available to man. If Doctor S. had studied literature beside medicine he would have known this as he would have known better than to take everything as the literal truth. For the psychoanalyst, instead, Zeno's lies are facts that he believes reveal the truth of Zeno's past. "E il dottore registrava. Diceva 'Abbiamo avuto questo, abbiamo avuto quello" " "The doctor noted everything. He would say 'We have had this, we have had that," "929). He ignores that the images recalled by Zeno are only graphic signs completely devoid of meaning, "In verità, noi non avevamo più che dei segni grafici, degli scheletri d'immagini" ("But really, we had nothing more than graphic signs, mere skeletons of images," 929).

In Svevo's version of psychoanalysis, the Oedipus complex is the problem that once recognized will provide the cure. Doctor S.'s efforts are geared toward identifying Zeno's dreams and confessions as his subconscious desire to love his mother and to kill his father. He is unaware, however, that Zeno is lying and making up stories just to please him. "Dimostravo così anche di aver capito perfettamente la malattia che il dottore esigeva da me. Edipo infantile era fatto proprio così: succhiava il piede sinistro della madre per lasciare il destro al padre" ("I thereby showed that I had grasped perfectly the disease that the doctor demanded of me. The infant Oedipus was just like that: he sucked his mother's left foot leaving the right one to the father," 934), or, "per far piacere al dottor S. inventavo nuovi particolari della mia infanzia che dovevano confermare la diagnosi di Sofocle" ("to please Doctor S. I invented new details of my childhood in conformity with Sophocles' diagnosis," 938). When Zeno lacks good dreams that can satisfy Doctor S., he invents others that fulfill his psychoanalytical expectations. Of course to Doctor S., or to any analyst, it matters little whether Zeno is telling the truth or not. To them everything counts. Zeno may think he has invented that he sucked his mother's left foot but as Doctor S. points out in the preface to the book, Zeno does not know that even his lies can shed light on his illness. "Se sapesse quante sorprese potrebbero risultargli dal commento delle tante verità e bugie ch'egli ha qui accumulate!" ("If he only knew what surprises lie in store for him in the analyses of the many truths and falsehoods that he has compiled here," 599). Psychoanalysis and Doctor S.'s claims that Zeno has been cured because he has identified in the Oedipus complex the cause of his illness are shown by Svevo to be instead another way in which man persists in his self-deluded state or, in Svevo's metaphor, in his illusions of "health." Svevo parodies psychoanalytical practice by alluding to the "literary" origins of the Oedipus complex and by pointing out, indirectly, that whatever Sophocles may have known of "health" it did not save him from death.

La mia cura doveva essere finita perché la mia malattia era stata scoperta. Non era altra che quella diagnosticata a suo tempo dal defunto Sofocle sul povero Edipo: avevo amata mia madre e avrei voluto ammazzare mio padre.

[I ought to have been cured for he had found out what was the matter with me. The 
diagnosis was exacty the sume that dead Sophocles mude on poor Oedipus: I had loved my mother and wanted to kill by father. (928, italics mine)]

As Sophocles never diagnosed Oedipus's problems as the Oedipus's complex, for "Sophocles," perhaps, we should read "Freud." Psychoanalysis, on the contrary, can be said to be symptomatic of man's real illness: his obsession with health. In one of the novel's key allegories, the episode of the fly, Svevo points to two basic errors in man's quest for health. The fly in question was bothering Zeno who in blowing it away damages one of its legs.

Era ferma, cretta e pareva più alta di prima perché una delle sue zampine era stata anchilosata c non poteva flettersi. Con le due zampine posteriori si lisciava assiduamente le ali. Tentò di muoversi, ma si ribaltò sulla schiena. Si rizzò c ritornò ostinata al suo assiduo lavoro.

[It (the fly) was standing right up, and seemed taller than before because one of its legs was paralysed by the blow and could not be bent. It was industriously cleaning its wings with its two hind legs. It tried to move, but fell over on its back. Then it picked itself up again and returned obstinately to its task. (683)]

The fly's efforts to overcome its debilitation lead Zeno to reflect on two errors in the insect's desperate attempts to return to normality.

Scrissi allora quei versi, stupito di aver scoperto che quel piccolo organismo pervaso da tanto dolore, fosse diretto nel suo sforzo immane da due errori: prima di tutto lisciando con tanta ostinazione le ali che non erano lese, l'insetto rivelava di non sapere da quale organo venisse il suo dolore; poi l'assiduità del suo sforzo dimostrava che c'era nella sua minuscola mente la fede fondamentale che la salute spetti a tutti $e$ che debba certamente ritornare quando ci ha lasciato. Erano errori che si possono facilmente scusare in un insctto che non vive che la vita di una sola stagione, e non ha tempo di far dell'esperienza.

[I wrote those verses in my surprise at discovering that the fly's tiny, pain-racked organism was acting on two mistaken assumption. First of all, in cleaning its wings so persistently the insect showed that it did not know which was the wounded limb. Secondly, its persistent efforts showed that it assumed health to be the right of everyone, and that though we have lost it we shall certainly find it again. These errors are quite excusable in an insect which only lives for one season and has no time to learn from experience. (683, italics mine)]

This quotation leaves implied that if we can excuse a fly for thinking this way, we cannot excuse man who lives longer than a season and has ample time to reflect and learn from experience. The insect's two errors are that although it feels pain he ignores the origin of that pain and, second, that it regards health as something it is his by right. These are man's two major delusions. Man deludes himself when he thinks that he knows the origin of his illness and he can cure it and when he presumes that he has a right to health. Psychoanalysis is one way that these errors are perpetuated. 
The proof that Svevo means the episode of the fly to signify the human condition and not that of the animal world becomes clear later in the novel where he contrasts the attitudes toward health in man and in the animal. In the case of the animal health is regained through the animal's innate ability to adapt to the demands of nature.

Qualunque sforzo di darci la salute è vano. Questa non può appartenere che alla bestia che conosce un solo progresso, quello del proprio organismo. Allorché la rondinclla comprese che per essa non c'era altra possibile vita fuori dell'emigrazione, essa ingrossò il muscolo che muove le suc ali $\mathrm{c}$ che divenne la parte più considerevole del suo organismo. La talpa s'interrò c tutto il suo corpo si conformò al suo bisogno. Il cavallo s'ingrandì e trasformò il suo piede. Di alcuni animali non sappiamo il progresso, ma ci sarà stato e non avrà mai leso la loro salute.

[Every effort to procure health is in vain. Health can only belong to the animal, whose sole idea of progress is that of his own body. When the swallow realized that emigration was the only possible life for her, she enlarged the muscles which worked her wings, and which became by degrees the most important part of her body. The mole went underground, and its whole body adapted itself to the task. The horse grew bigger and changed the shape of his foot. We know nothing about the development of certain animals, but it must have existed, and can never have injured their health. (955, italics mine)]

The animal never loses its health because when it ceases to function in the old established way, it adjusts. It tries to survive any way it can. The same cannot be said for man. Unlike the animal, man has not learned to adjust, on the contrary, he has tried to substitute himself to Nature forcing it to adjust to his ways. "L'uomo s'è messo al posto degli alberi e delle bestie ed ha inquinata l'aria, ha impedito il libero spazio" ("Man has taken the place of the trees and of the animals, has poisoned the air and has eliminated the open spaces," 954). At first the "ordigni," as with the animal, were extensions of man himself, necessary to his survival. Later, however, they become instruments for the dissemination of destruction and of illness.

I primi suoi ordigni parevano prolungazioni del suo braccio e non potevano essere cfficaci che per la forza dello stesso, ma, oramai, l'ordigno non ha più alcuna relazione con l'arto. Ed è l'ordigno che crea la malattia con l'abbandono della legge che fu su tutta la terra creatrice.

[The carliest tools were extensions of his arm, and could not be used except by the strength of the arm. Nowadays, however, the tool bears no longer any relation to the arm. It is the tool that creates the disease by abandoning the law by which everything was created on earth. (955)]

Natural selection based on the law of the survival of the fittest, to which the animal is subject, no longer applies to man. Survival for man is in terms of the greatest number of "ordigni" - instruments of destruction - he possesses 
whereby he survives by destroying others. "La legge del più forte spari e perdemmo la selezione salutare. Altro che psico-analisi ci vorrebbe: sotto la legge del possessore del maggior numero di ordigni prospereranno malattie e ammalati" ("The law of the strongest disappeared, and the healthy natural selection was lost. We need something more than p.sychounaly'sis to help us. Under the law of the greatest accumulation of tools, disease will prosper and the diseased will grow ever more numerous," 955, italics mine). Man's illness cannot be cured by psychoanalysis or by any other cure. The only cure, the only possible return to health, in Svevo's pessimistic and apocalyptic vision, is a world-wide catastrophe that would put an end to the human race. "Forse attraverso una catastrofe inaudita prodotta dagli ordigni ritorneremo alla salute" ("Perhaps an incredible catastrophe brought about by these tools will lead us back to health," 955). "Ci sarà un'esplosione enorme che nessuno udrà e la terra ritornata alla forma di nebulosa errerà nei cieli priva di parassiti e di malattie" ("There will be a tremendous explosion that none will hear and the earth returned to its nebulous state will wander through the sky free at last from parasites and disease," 955). Only with the destruction of the planet earth as we know it, illness will finally disappear because for Svevo that illness is man. The final explosion that will wipe man from the face of the earth is the final irony. The tool that man developed initially in order to survive, and later becomes an instrument of domination and destruction, finally turns against him and destroys him altogether. The "health" that man seeks will be achieved only with the end of man. At that moment, time too will finally come to a halt and cease to exist. In the explosive finale of the novel, Svevo's supreme, absolute irony puts an end to time and to all of man's illusions at one stroke.

Zeno's "coscienza," in Eleatic fashion, disrupts our ordinary perception of the world and reveals it in all it nakedness. Zeno, who is said to have the sickness of the word "la malattia della parola" (659), disfigures everything he says, "come aprivo la bocca svisavo cose o persone perché altrimenti mi sarebbe sembrato inutile di parlare" ("as I opened my mouth I disfigured things or people because otherwise it would have been difficult for me to speak," 659). His language is not the language of communication but of disfiguration. It reveals the "sickness" of the figure which hides the real sickness. This is not a conscious action on Zeno's part. As we have said earlier, Zeno's "coscienza" is ironic and functions despite his ordinary, commonplace mentality. "Coi mici sforzi a me toccava come a quel tiratore cui era riuscito di colpire il centro del bersaglio, però di quello posto accanto al suo" ("With my efforts I was like that marksman who always hits the target next to his," 665). This ironic knowledge is described as a knowledge without knowing: "Zeno ... senza saperlo, sapete molte cose, mentre i miei professori sanno esattamente tutto quello che sanno" ("Zeno. . . , without knowing it you know many things while my professors know just what they know," 706). Through Zeno's ironic "coscienza" speaks a wisdom which is not his and 
is not ordinary knowledge. Those who know (professors or psychoanalysts) possess only a knowledge of facts which in the last instance is useless and misleading, whereas Zeno's ironic "coscienza" is a knowledge that goes to the heart of the problem and does so by questioning and "disfiguring" examples of health. "Io sto analizzando la sua salute, ma non ci riesco perché m'accorgo che, analizzandola, la converto in malattia" ("I am analysing his health but I am not succeeding because 1 realize that by analysing it I convert it to illness" 727). Zeno reminds us of that philosopher who went looking for a wise man but always found that those reputed wise were more ignorant than he. Zeno is for Svevo an ironic tool, "ordigno," with which to criticize a society obsessed with health which to Svevo appeared hopelessly and incurably sick.

The reading of La coscienza di Zeno and the search for its meaning(s) are preoccupations rather similar to an obsession with health; the reader or the critic is not different from the analyst. As I have already indicated, in some instances the reader-critic indeed has become the analyst and has placed both Zeno and Svevo's novel on the couch. Other times the reader-critic has downplayed Svevo's pessimism by attributing it to the erratic and extremist behavior of his protagonist or simply to the shortcomings of the social class that he represents. ${ }^{9}$ From the account I have given of the novel it would seem instead that one of the few possible ways of reading this novel lies in adopting the definition of health that Svevo reserves for man. Just as the "coscienza" of not having been cured is the best proof of health, the best proof that one is reading this novel with a certain degree of accuracy is in the awareness that its meaning is not what one thought it to be at first but always other and different in spite of our efforts. This is a reading based not on the professional knowledge of what we expect or know the novel to be but on the ironic Eleatic knowledge that things are never what they seem logically to be.

University of Alberta

\section{NOTES}

1 The epigraph literally translates: "Things do not appear as well when the eyes are too wide open." All references to La Coscienza di Zeno will be included in the text. Extensive modifications to de Zoete's translation have been made throughout. The translation of other texts is mine.

2 Eduardo Saccone who proposes a psychoanalytical reading of the novel reads the phrase "Ricordo tutto, ma non intendo niente" as a division within the subject that puts into question its ability to know itself (8).

3 Beside Saccone's Lacanian reading we should also mention the psychoanaltical readings of Elio Gioanola and Carlo Fonda. For examplc, Fonda's premise and justification for his Freudian reading of Zeno and of the novel is the following, "la premessa fondamentale, l'ultima convinzione che sta alla base di tutto il nostro studio . . è che, in questo romanzo, Svevo, ispirato indubbiamente dalla letlura di Freud, ha tentato di fare l'esperimento di vivere, 
per la durata del racconto, nella psiche malata di un isterico" ("The fundamental premise, the ultimate belicf which is at the basis of all our study is that Svevo, who is without doube inspired by a reading of Freud, has tried the experiment of living for the duration of the story in the diseased psychosis of an hysteric," 9). Fonda discounts the possibility that Svevo might be humoring the practice of psychoanalysis. "Nei riteniamo che questo esperimento lo abbia fatto seriamente e non per beffa..." ("We firmly believe that this experiment was made scriously and not in jest..." 9).

4 Frecero points out the similarities between Zeno Cosini and Zeno of Elea. "Svevo has called his character Zeno ... precisely because his character is an embodiment of the spirit of the Eleatic, secking to reconcile reality to reason" (17). Freccero understands this reference to the Greck philosopher as an attempt by the author to underscore Zeno's own personal paradox hinted at the beginning of the book. "The first chafter of Zeno's novel presents us with an old paradox in unique form: how can one reconcile the movement of life, animal health, with the transversal static cuts made by the intellect? How can one be and know that he is being? The paradox is a form of the ancient paradox of Zeno of Eleia (sic), transposed from the mysteries of space and motion to those of Augustinian duration and timc" (17).

5 One of the few studies solely dedicated to irony in the novel is Petersen's Le strutture dell'ironia ne La Coscienza di Zeno di halo Sievo. Petersen identifies ironic themes and ironic elements in the novel but does not provide an overall reading of the novel.

6 The only true analysis for Zeno, and for Svevo, is the analysis of the urine sample. "Ecco finalmente una vera analisi e non più una psico-analisi . . Qui, invece, tutto cra verità" "Here finally was a true analysis and no longer a psycho-analysis . . Here cverything was truth" (438). Svevo/Zeno believe that psychoanalysis could be better characterized as "I'avventura psichica" ("psychic adventure" 938).

7 Zeno's situation calls to mind the punishment that Sartre's characters suffer in Huis Clos where hell is defined as the false image others have of ourselves to which they condemn us and which we will never be able to change.

8 Svevo, as is well known, became acquainted with psychoanalysis through Edward Weiss, one of the major influential psychoanalyst in Italy at the time. His enthusiasm made him even attempt a translation of Freud's On dreams. This interest in psychoanalytical theory, however, does not extend to the practice. Svevo was disenchanted with it when his brotherin-law Bruno, who had gone to Vienna to be analyzed by Freud, returned even more neurotic than before. For accounts in English see for instance Furbank Italo Sievo (especially 1067, 177-81). Svevo's interest in "psychoanalytical" problems predates even Freud, as he says himsclf: "Si dice che Senilità e La coscienza di Zeno le abbia scritte sotto la sua influenza (Freud's). Per Senilità m'è facile di rispondere. Io pubblicai Senilità nel 1898 e allora Freud non esisteva o in quanto esisteva si chiamava Charlot" ("They say that Senilità and La coscienza di Zeno were written under Freud's influence. For Scnilita the answer is easy, I published Senilita in 1898 and Freud did not exist then or if he did his name was Charlot"). (Camerino, 318). This quotation also implies that even more than Freud, the greatest influence on Svevo was Charlic Chaplin and his character Charlot. See Svevo's other comment quoted also by Camerino, that "Freud non può aver per la letteratura altra importanza di quella ch 'ebbero a suo tempo Nietzsche o Darwin" ("Freud could not be more relevant for literature than either Nietzsche or Darwin," 319). Svevo's literary use of Freud, Nietzsche or Darwin, did not imply that he shared their philosophy. In the case of Freud and with respect to psychoanalysis's claim to cure, Svevo, as Camerino reminds us, believed that "Freud sarebbe stato buono più per i romanzieri che per gli ammalati" ("Freud would have been more useful for novelists than for the sick," 319). Svevo's similar preoccupation with the unconscious explains why, in sending a copy of La coscienza di Zeno to Freud, he expected to be commended by him. As Lebowitz suggests, perhaps Svevo wanted from Freud the same accolade that he had sent to Arthur Schnitzler praising him for the depth of his artistic intuitions (29-30). But just as Weiss, who at the time was a personal friend 
of Freud, reneged on his promise to review La coscienza di Zeno because "the novel had nothing whatever to do with psychoanalysis" (Furbank, 178), so Freud, if he read the novel, not only must have felt the same but must have felt slighted by a novel that however full of insights into human nature also made fun of his psychoanalysis.

9 Debencdetti, for instance, explains the incoherence of Zeno's behaviour and his extreme manifestations of love and hatred as stemming from the author's feelings of alienation as a Jew and from his decp-seated antisemitism. "Ed ha assunto quel tono di apologia a rovescio, particolare all'antisemitismo dcgli ebrei, in cui l'odio e l'amore più sviscerati vanno commisti in un abbraccio mostruoso ... Quel tono ricorda da vicino quello che riconoscevamo in Svevo, giudice e confessore del suo protagonista" " $\mathrm{He}$ has taken on that apologetic tone in reverse, typical of jewish antisemitism, whereby the deepest love and hatred can be found together in a monstrous embrace... That tone reminds us closely of what we recognized in Svevo, judge and confessor of his protagonist," 285). Or when Zeno is seen to be emblematic of the ambiguity and impotence fo the middle classes by Lunetta.

\section{WORKS CITED}

Camerino, Giuseppe Antonio. Italo Svevo. Torino: UTET, 1981.

Debcnedetti, Giacomo. Saggi critici. Milano: Mondadori, 1955.

Fonda, Carlo. Sievo e Freud: Proposta di interpretazione della Coscienza di Zeno. Ravenna: Longo, 1978.

Freccero, John. "Zeno's last cigarette." MLN 77 (1962): 3-23.

Furbank, P.N. Italo Svevo: The Man and the Writer. London: Secker \& Warburg, 1966.

Gioanola, Elio. Un killer dolcissimo: Indagine psicanalitica sull'opera di Italo Svevo. Genova: Il Melangolo, 1979.

Lebowitz, Naomi. Italo Svevo. New Brunswick, N.J.: Rutgers Press, 1978.

Lunetta, Mario. Invito alla lettura di Italo Svevo. Milano: Mursia, 1976.

Petersen, Lene Waage. Le strutture dell'ironia ne La Coscienza di Zeno di ltalo Svevo. Revue Romane. Numéro spécial 20 (1979). Etudes Romanes de l’Université de Copenhague.

Saccone, Eduardo. Commento a Zeno: Saggio sul testo di Svevo. Bologna: Il Mulino, 1973.

Svevo, Italo. La Coscienza di Zeno. Opera Omnia. Ed. Bruno Maier. Vol. 2. Milano: Dall’Oglio, 1969. 4 vols. 1966-1969.

Putnam, 1930. 